\title{
Socioeconomic Profile of Milk Producers in the Municipality of Olho D'agua das Flores, Alagoas, Brazil
}

\author{
José Crisólogo De Sales Silva ${ }^{*}$, Ademilson Neris Dos Santos ${ }^{2}$, Pedro Alexandre Barbosa Pereira Miranda ${ }^{3}$, \\ Andrei Atroshenko ${ }^{4}$
}

${ }^{1}$ Professor, Animal Science Department, Campus II, State University of Alagoas, Uneal, BRAZIL
${ }^{2}$ Bovine Milk Production, Balde Cheio Division, State University of Alagoas, Uneal, BRAZIL
${ }^{3}$ Zootechnist, Animal Science Department, Federal University of Alagoas, Ufal, BRAZIL
${ }^{4}$ Economist, Department of Economics, London School of Economics and Political Science, London, UK

*E-mail for correspondence: josecrigot@ hotmail.com

Cell Phone: +55 829960424

Received: Jul 01, 2015;

Accepted: Jul 13, 2015;

Published: Aug 06, 2015

Source of Support: Nil

No Conflict of Interest: Declared

\begin{abstract}
Bovine milk is widely considered to be one of the most nutritious foods. It is rich in calcium and other ingredients, such as vitamins, protein and phosphorus. The municipality of Olho d'Água das Flores in the state of Alagoas, north-eastern Brazil is located in the microregion of Batalha of the mesoregion of Sertão Alagoano. The interviews for this study have been conducted over a period of 150 days between October 2011 and February 2012, whereby a questionnaire was used to collect the required information. Of the 41 producers interviewed, 37 were family farmers, as defined by the law $n^{\circ}$ $11.326 / 2006$ of Brazil, relevant legislation currently regulating the classification of producers as "family farmers", corresponding to $90 \%$ of the sample. Despite the properties of those interviewed exhibiting characteristics of differentiated production, continued high-quality technical assistance is the major necessity of the producers, hence the importance of understanding their socioeconomic profile and that of their properties.
\end{abstract}

Keywords: Family farms, Associations, Dairy farming

\section{INTRODUCTION}

Bovine milk is widely considered to be one of the most nutritious foods. It is rich in calcium and other ingredients, such as vitamins, protein and phosphorus.

According to the Foundation of Food and Agriculture Organization of United Nations (FAO), Brazil is currently the fifth largest producer of milk globally, behind only USA, China, India and Russia. According to the Brazilian Corporation of Agricultural Research (EMBRAPA), the production capacity of milk in 2011 was 32.3 billion litres. The Agricultural Census conducted by The Brazilian Institute of Geography and Statistics (IBGE, 2006) estimated that approximately $25 \%$ of the 5,2 million rural establishments in Brazil produce milk.

Bovine milk culture is of significant socioeconomic importance in Brazil, occurs throughout the country (MÜLLER, 2002), is produced by 1,3 properties and creates over 4 million jobs (BERGAMACHI, 2010).

Thus, milk is one of the most important agricultural products in Brazil (EMBRAPA, 2002), with local production activity becoming increasingly competitive in the sector. Therefore, it is of great importance to quantify and qualify the factors, which influence production most significantly, as this would lead to real gains in both the quantity and quality of milk produced to satisfy the national demand (COLDEBELLA et. al., 2004).

In the state of Alagoas, dairy cattle farming is considered an activity with the second-highest potential for regional job creation and income generation (Oliveira, 2012), only surpassed by sugarcane production. However, according to EMBRAPA, the production potential of milk in 2011 was only 230 million litres, constituting $0.7 \%$ of national production. The municipality of Olho d'agua das Flores is located in a "dairy region"; according to the data collected by IBGE, milk production in the municipality grew $45 \%$ in 6 years. According to the findings of IBGE (2010), the municipality produced approximately 3,25 million litres of milk, thus justifying the need to understand the profile of the local producers in terms of their socioeconomic conditions. In family farming, the members of the respective family handle both the labour and the management of the property. Therefore, the paradigm that these properties are necessarily synonymous with small-scale production must be broken. (FERNANDES, 2009). 
This study has the objective of discovering the socioeconomic profile of the dairy producers in the municipality of Olho d'Agua das Flores in the state of Alagoas.

\section{Material And Methods}

The municipality of Olho d'Água das Flores in the state of Alagoas, north-eastern Brazil is located in the microregion of Batalha of the mesoregion of Sertão Alagoano. The municipality has an area of $183,441 \mathrm{~km}^{2}$ and a population of 20.364 inhabitants, including the rural population of 6.375 inhabitants and the urban population of 13.989 inhabitants, corresponding to $31 \%$ and $69 \%$ of total population, respectively (IBGE, 2010).

The geographical coordinates of the municipality are $09^{\circ} 32^{`} 10^{\prime \prime}$ latitude and $37^{\circ} 17^{\prime} 38^{\prime \prime}$ longitude.

This study employed the methodology previously recommended by Mattar (2007), whereby the primary data, never previously been collected, tabulated nor analysed, is gathered through direct communication, interviews and questionnaires.

The interviews were conducted during a period of 150 days between October 2011 and February 2012, and questionnaires were used for data collection. The farmers interviewed were members of the following regional associations of dairy producers: Associação Boa Esperança de Produtores de Leite da Camaratuba, Associação dos Produtores de Leite da Mulatinha and Associação dos Produtores de Leite da Samambaia; totaling 84 members. Of those, 41 were interviewed, forming a sample of $48,8 \%$.

Subsequently, Microsoft Excel was used for data tabulation.

\section{Results AND Discussion}

All of the producers interviewed were male descendants of farmers born in the state of Alagoas, Brazil.

Of the 41 producers interviewed, 37 were family farmers, as defined by the law $\mathrm{n}^{\circ} 11.326 / 2006$ of Brazil, relevant legislation currently regulating the classification of producers as "family farmers", corresponding to $90 \%$ of the sample.

The average age of those interviewed was 49 years. The interrelationship between age and the level of education is presented in Table 1 below.

Table 01 - Interrelationship between the age of those interviewed and the level of education attained in Olho d'agua das Flores, 2012.

\begin{tabular}{|c|c|c|c|c|c|c|c|c|c|c|c|c|}
\hline \multirow[t]{2}{*}{$\begin{array}{l}\text { Age/Level of } \\
\text { Education }\end{array}$} & \multicolumn{2}{|c|}{$\begin{array}{l}\text { Have not } \\
\text { attended } \\
\text { school }\end{array}$} & \multicolumn{2}{|c|}{$\begin{array}{l}\text { Incomplete } \\
\text { primary } \\
\text { education }\end{array}$} & \multicolumn{2}{|c|}{$\begin{array}{l}\text { Complete } \\
\text { primary } \\
\text { education }\end{array}$} & \multicolumn{2}{|c|}{$\begin{array}{l}\text { Incomplete } \\
\text { secondary } \\
\text { education }\end{array}$} & \multicolumn{2}{|c|}{$\begin{array}{l}\text { Complete } \\
\text { secondary } \\
\text { education }\end{array}$} & \multicolumn{2}{|c|}{ Total } \\
\hline & $\mathrm{AF}$ & $\mathrm{RF} \%$ & $\mathrm{AF}$ & $\mathrm{RF} \%$ & $\mathrm{AF}$ & $\mathrm{RF} \%$ & $\mathrm{AF}$ & $\mathrm{RF} \%$ & $\mathrm{AF}$ & $\mathrm{RF} \%$ & $\mathrm{AF}$ & $\mathrm{RF} \%$ \\
\hline 25 to 40 years & 0 & 0 & 2 & 4,9 & 1 & 2,4 & 2 & 4,9 & 6 & 14,6 & 11 & 26,8 \\
\hline 41 to 55 years & 3 & 7,3 & 14 & 34,1 & 5 & 12,2 & 1 & 2,4 & 0 & 0 & 23 & 56,1 \\
\hline$>55$ years & 2 & 4,9 & 4 & 9,7 & 1 & 2,4 & 0 & 0 & 0 & 0 & 7 & 17,1 \\
\hline Total & 5 & 12,2 & 20 & 48,7 & 7 & 17 & 3 & 7,3 & 6 & 14,6 & 41 & 100 \\
\hline
\end{tabular}

AF- Absolute Frequency, RF\% - Relative Frequency as a percentage of those interviewed

Research found the group between the ages of 25 and 40 years to be the most educated. However, the largest number of producers had not completed primary education, $48,7 \%$ of the sample, and the majority of those was between 41 and 55 years of age. Among the farmers over 55 years old, the highest level of completed education was the primary school. Thereby, it can be stated that the oldest demographics of the producers are also the least educated.

A similar study undertaken by Junior (2007), in the town of Garanhuns, Pernambuco, Brazil, found the average age of the producers to be 47 years and the level of education attained to be positively correlated with levels of production. In addition, according to Santos (2009), the majority of the producers in the municipality of Catingueira, Pernambuco, Brazil, was between 30 and 60 years and the highest level of education attained by them was incomplete primary education.

Average gross monthly revenue of those interviewed was approximately 2,5 minimum salaries. However, $51 \%$ of the producers received one minimum salary from dairy farming. Further, it must be considered that the gross revenue only constitutes the total receipts, without accounting for the costs of production, remuneration and depreciation of the capital invested.

The average total area of the properties was found to be 13.4 hectares. $80 \%$ of the properties had an area less than 20 hectares, however, only $41 \%$ were smaller than 10 hectares, evidence in favour of the majority of the producers being characterized as family farmers. The access to information regarding dairy activity was also conducted in the interviews, whereby only 13 producers stated that they had received technical assistance, 31,7\% of the sample. Meanwhile, television programmes were cited by $100 \%$ as a source of information regarding dairy activity. The revenues of producers exhibited a significant dispersion, $51 \%$ of them had up to one minimum salary derived from the dairy activity. At the same time, the mean monthly revenue of the producers was $\mathrm{R} \$ 1.624,00$, which corresponds to approximately 2.5 minimum salaries. 
A study by Ferreira et. al. (2007) demonstrated that the average remuneration of dairy producers in the northeast of the state of Parana, Brazil, was approximately 3.5 minimum salaries.

Diagram 01 - Gross revenue of the dairy producers in the municipality of Olho d'Agua das Flores, Alagoas, Brazil, 2012.

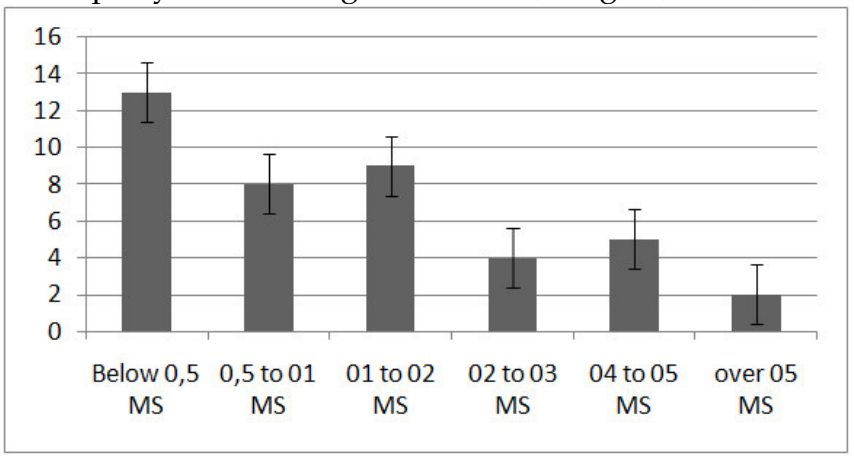

MS = Minimum Salary

All of the producers stated that dairy activity was the primary source of their income. However, research indicated that over $50 \%$ of the producers had alternative sources, some of them receiving pensions, others employed as public workers, freelancers or being beneficiaries of social assistance programmes.

The price of milk paid to the producer varied between $R \$$ 0,55 a $R \$ 1,00$ per litre; this variation occurred due to the subsequent destination of the milk sold. Milk distributed through intermediaries resulted in lower remuneration, and the higher levels of income were associated with milk sold informally in the urban area. However, the majority of the producers realized their produce to the local cooling tanks in the communities and received an average of $\mathrm{R} \$ 0,73$ for a litre of milk.

Table 02 - Types of labour employed in the municipality of Olho d'agua das Flores, Alagoas, Brasil, 2012.

\begin{tabular}{llc}
\hline Type of labour & AF & RF \% \\
\hline Only family & 9 & 22,00 \\
Family and temporary & 26 & 63,00 \\
Family, fixed and temporary & 2 & 5,00 \\
Permanent and temporary & 4 & 10,00 \\
TOTAL & $\mathbf{4 1}$ & $\mathbf{1 0 0 , 0 0}$ \\
\hline
\end{tabular}

$\mathrm{AF}=$ absolute frequency and $\mathrm{RF} \%=$ relative frequency as a percentage.

The results demonstrate that $63 \%$ of the properties utilized family and temporary labour, indicating the dependence of the farmers on temporary workers, which could be freelance workers or other family farmers. The remunerations were in the forms of either daily rates or wages, with the former group lacking the benefit of a formal contract.

These results differ from those found by the Corporation of Technical Assistance and Rural Extension of Ceará EMATERCE (2006) in the region of Baixo Jaguaribe in Ceará, Brazil, where the majority of property owners utilized only family labour in $30.7 \%$ of cases, and temporary labour was employed by only $30 \%$ of them.

\section{CONCLUSION}

Despite the properties of those interviewed exhibiting characteristics of differentiated production, continued high-quality technical assistance is the major necessity of the producers, hence the importance of understanding their socioeconomic profile and that of their properties.

\section{REFERENCES}

Coldebella, A.; Machado, P. F.; Demetrio, C. G. B. Contagem de Células Somáticas e Produção de Leite em Vacas Holandesas Confinadas. Revista Brasileira de Zootecnia, v.33, n.3 p. 623-634, 2004. Disponível em: <http://www.scielo.br/pdf/rbz/v33n3/2148 3.pdf> [acesso em: 02/04/12].

Ematerce. Empresa de Assistência Técnica e Extensão Rural do Ceará. Levantamento do Perfil dos Produtores de Leite e os Impactos da Assistência Técnica na Região do Baixo Jaguaribe, Estado do Ceará. 2006. 5p.

Empresa Brasileira de Pesquisa Agropecuária. Embrapa Gado de Leite. Sistema de Produção de Leite no Cerrado. 2002. Disponível em: <http://sistemasdeproducao.cnpt ia.embrapa.br/FontesHTML/Leite/LeiteCerrado/importan cia.html $>$. Acesso em: $<23 / 03 / 12>$.

Empresa Brasileira de Pesquisa Agropecuária. Estatísticas do Leite. Juiz de Fora: Embrapa Gado de Leite, 2011. Disponível em: <http://www.cnpgl.embrapa. $\mathrm{br} /$ nova/informacoes/estatisticas/estatisticas.php $>$. Acesso em: $<01 / 04 / 2012>$.

Empresa Brasileira de Pesquisa Agropecuária. Estatísticas do Leite. Juiz de Fora: Embrapa Gado de Leite, 2012. Disponível em: <http://www.cnp gl.embrapa.br/nova/informacoes/ estatisticas/estatisticas.php>. Acesso em: <01/04/2012>.

Fernandes, A. E. B. O Perfil da Agricultura Familiar Brasileira. 2009. Disponível

em:

<http:/ / www.webartigos.com/artigos/o-perfil-da-

agricultura-familiar-brasileira/16496 /\#ixzz15shwBQmr>. Acesso em: <01/04/12>.

Ferreira, L. R.; Takarashi, C. N.; Donega, M. A.; Castaldo, J. H.; Branco, A. M. S. Análise do Perfil Técnico e Socioeconômico de uma Cooperativa de Produtores de Leite do Noroeste do Paraná. XLV Congresso da Sociedade Brasileira de Economia. Londrina - PR, 2007. 20p.

IBGE. Instituto Brasileiro de Geografia e Estatística. Censo Agropecuário 2006. Disponível em: <http://www.ibge.gov.br/home/estatistica/economia/agr opecuaria/censoag ro/default.shtm $>$. Acesso em: $<20 / 02 / 12>$.

IBGE. Instituto Brasileiro de Geografia e Estatística. Pesquisa Pecuária Municipal. Disponível em: $<$ http:/ / www.sidra.ibge.gov.br/bda/tabela/listabl.asp?c= $74 \& z=t \& o=23>$. Acesso em: $<20 / 02 / 12>$.

Instituto Brasileiro de Geografia E Estatística. Censo Agropecuário 2006. Disponível em: <http://www.ibge.gov.br/home/estatistica/economia/agrope cuaria /censoagro/default.shtm $>$. Acesso em: $<20 / 02 / 12>$.

Instituto Brasileiro de Geografia E Estatística. Censo Demográfico 2010. Disponível em: <http://www.ibge.gov.br/cidadesat/topwindow.htm?1>. Acesso em: $<17 / 05 / 2012>$. 
Junior, M. de A. P.. Perfil dos produtores de leite do município de Garanhuns. Garanhuns, 2007.

Mattar, F. N.. Pesquisa de Marketing 1: Metodologia e Planejamento. São Paulo: Atlas, 2007.

Muller, E.E. Qualidade do leite, celulassomaticas e prevenção da mastite. In: II Sul-Leite: Simpósio sobre sustentabilidade da pecuária leiteira na região Sul do Brasil, 2002, Toledo. Anais... Toledo - PR, p. 206-217, 2002.
Oliveira, A. W.. Avaliação de indicadores referência em propriedades leiteiras do Estado de Alagoas. 2012. Dissertação - Centro de Ciências Agrárias, Universidade Federal de Alagoas, Rio Largo, 2012.

Santos, P. L. S.; Azevedo, E. O.. Perfil sócio-econômico de produtores de leite do Estado da Paraíba, Brasil. Revista Caatinga, v. 22, n. 4, p. 4, out-dez, 2009.

$--0--$ 